\title{
Nota Científica / Short Communication: New records in Schizachyrium (Poaceae - Andropogoneae) for Rio Grande do Sul and for Brazil
}

\author{
Novos registros em Schizachyrium (Poaceae - Andropogoneae) para o Rio Grande do Sul
} e o Brasil

Cassiano Aimberê Dorneles Welker ${ }^{1,2}$ \& Hilda Maria Longhi-Wagner ${ }^{1}$

\begin{abstract}
The genus Schizachyrium Nees includes ca. 60 species, 15 of them previously cited for Brazil. Schizachyrium bimucronatum Roseng., B.R. Arrill. \& Izag. is a new record for Brazil and S. lactiflorum (Hack.) Herter, for the State of Rio Grande do Sul. Morphological data to aid in the identification of the two species, including short descriptions and illustrations, as well as data on their geographical distribution and habitat, are provided. Key words: Gramineae, Southern Brazil, taxonomy.

Resumo

O gênero Schizachyrium Nees inclui cerca de 60 espécies, das quais 15 já foram citadas para o Brasil. Schizachyrium bimucronatum Roseng., B.R. Arrill. \& Izag. está sendo citada pela primeira vez para o Brasil e S. lactiflorum (Hack.) Herter, para o Rio Grande do Sul. São fornecidos dados morfológicos para auxiliar na identificação das duas espécies, incluindo breves descrições e ilustrações, além de dados de distribuição geográfica e hábitat.

Palavras-chave: Gramineae, sul do Brasil, taxonomia.
\end{abstract}

The genus Schizachyrium Nees (Poaceae Andropogoneae) includes ca. 60 species distributed in tropical and subtropical regions of the world (Clayton \& Renvoize 1986). It is represented in the Americas by ca. 30 species, distributed from Canada to Argentina (Filgueiras 2003). Peichoto (2010) cited 15 species for Brazil, 12 of them listed in the recent Catalogue of Plants and Fungi of Brazil (Zanin 2010).

This paper presents two new records of species of Schizachyrium, one for Brazil and one for the State of Rio Grande do Sul. Descriptions and illustrations of the two taxa, as well as data on their geographical distribution and habitat, are provided.

The study was based on revision of the literature, field collections and specimens from the following herbaria: BLA, CNPO, HAS, HUCS, HUI, HVAT, ICN, PACA, PEL, RSPF and SMDB (acronyms according to Thiers 2011 and RBH 2011). The collected material was deposited at the ICN herbarium.
Schizachyrium bimucronatum Roseng., B.R. Arrill. \& Izag. is reported for the first time for Brazil. Although Schizachyrium lactiflorum (Hack.) Herter has been previously cited for other areas in Brazil (Peichoto 2010), it is here cited first time for the State of Rio Grande do Sul. Both species are additions to the recently published Catalogue of Plants and Fungi of Brazil (Zanin 2010).

Regarding conservation aspects none of the two species here discussed seem to be threatened as they have a wide distribution and are frequent in other South American countries (Peichoto 2010), although less common in Brazil.

1. Schizachyrium bimucronatum Roseng., B.R. Arrill. \& Izag., Bol. Fac. Agron. Univ. Montevideo 103: 32, f. 8. 1968

Fig. 1a-c

Perennial, caespitose, $48-115 \mathrm{~cm}$ high. Leaf blades 7-23 cm long, (5.5-)6-12(-15) mm wide, conspicuously glaucous. Inflorescence

\footnotetext{
${ }^{1}$ Universidade Federal do Rio Grande do Sul. Depto. Botânica, Av. Bento Gonçalves 9500, Bl. IV, prédio 43432, Campus do Vale, Bairro Agronomia, $91501-970$, Porto Alegre, RS, Brazil.

${ }^{2}$ Author for correspondence: cassiano_welker@yahoo.com.br
} 


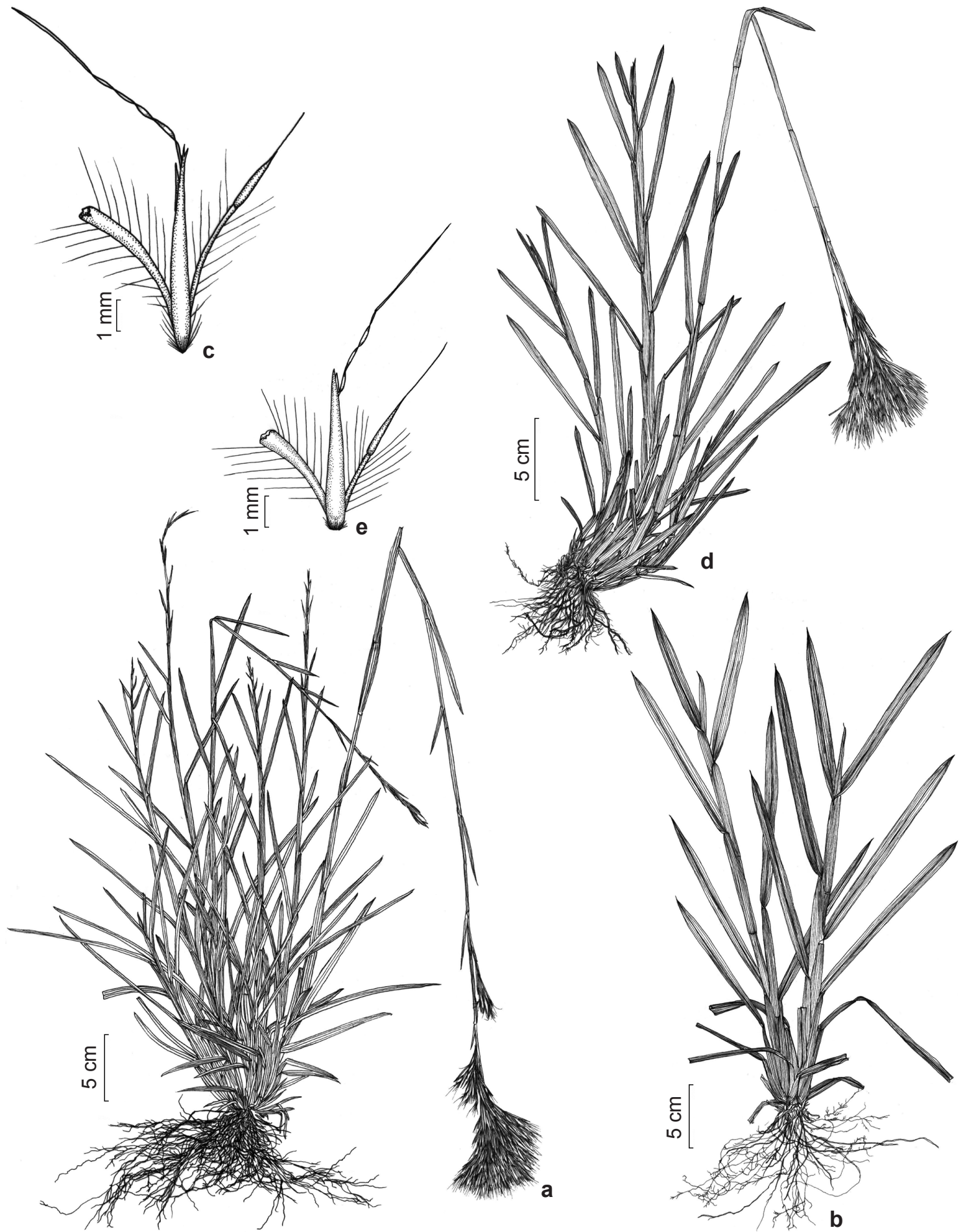

Figure 1 - a-c. Schizachyrium bimucronatum - a. habit, flowering stage (C.A.D. Welker 208); b. habit, vegetative stage (H.M. Longhi-Wagner \& C.A.D. Welker 10843); c. pair of spikelets and rachis internode (C.A.D. Welker 208). d-e. Schizachyrium lactiflorum (H.M. Longhi-Wagner \& C.A.D. Welker 10844) - d. habit, flowering stage; e. pair of spikelets and rachis internode. 
corymbiform, subcongeste, or narrowly oblong, with 50-130 racemes; rachis internodes and pedicels flexuous at maturity. Spatheole 16-22 $\mathrm{mm}$ long. Peduncle of each raceme $4-11 \mathrm{~mm}$ long, shorter than the spatheole, at maturity. Rachis internode 5-6.5 mm long. Sessile spikelet: lower glume 5.5-7 mm long, 0.4-0.6 mm wide between the keels; upper lemma awned, the awn 11-15 mm long. Pedicellate spikelet: lower glume 1.7-3 mm long, awned, the awn 1.5-3.2 mm long. Material examined: Alegrete, Cerro do Tigre, 7.VI.2007, E. Freitas (HVAT 2140); 8.I.2009, C.A.D. Welker 198, 201 (ICN); 15.XII.2009, C.A.D. Welker 225 (ICN); 6.II.2012, C.A.D. Welker 405 (ICN); Fazenda Cerro do Tigre, 6.I.2007, E. Santos (HVAT 1763, ICN 152719). Santiago, BR-287 to São Vicente do Sul, 21.XII.2010, H.M. Longhi-Wagner \& C.A.D. Welker 10843 (ICN). São Francisco de Assis, RST-377, near km 320, 11.I.2009, E. Freitas 660 (ICN); near Arroio Araçá, 8.I.2009, C.A.D. Welker 208 (ICN); 5.II.2012, C.A.D. Welker 400 (ICN).

This species occurs in Paraguay, Argentina (Rosengurtt et al. 1968; Peichoto 2010) and Brazil, in the Pampa biome, mainly in the Southwestern Rio Grande do Sul. Schizachyrium bimucronatum occurs in grasslands with sandy soils, dry or seasonally wet, or in rocky soils and in rock crevices.

Schizachyrium bimucronatum is easily recognized in the field by its leaves and culms conspicuously glaucous, flattened at the base, and by the leaf blades wider than those of other species of the genus occuring in Brazil. According to Peichoto (2010), this species presents leaf blades (5-)7-9 mm wide, but leaf blades up to $13.5 \mathrm{~mm}$ wide were mentioned by Rosengurtt et al. (1968) in the diagnosis of the species. Plants of the population represented by the specimen Longhi-Wagner \& Welker 10843 (ICN) have even wider leaf blades, up to $15 \mathrm{~mm}$ wide, and present the base of the plants strongly flattened (Fig. 1b).

Schizachyrium bimucronatum is morphologically similar to $S$. microstachyum (Desv. ex Ham.) Roseng., B.R. Arrill. \& Izag., being distinguished mainly by the glaucous and wider leaf blades, which are greenish and 3-6 mm wide in S. microstachyum. Furthermore, plants of S. microstachyum present the lower glume of the sessile spikelets and the rachis internodes shorter, 3.5-4.3(-4.5) $\mathrm{mm}$ long and 3.5-5 $\mathrm{mm}$ long, respectively. Schizachyrium microstachyum occurs from Mexico to Argentina, Uruguay and Brazil (Filgueiras 2003; Peichoto 2010).
2. Schizachyrium lactiflorum (Hack.) Herter, Revista Sudamer. Bot. 6(5-6): 135. 1940. Andropogon condensatus Kunth subvar. lactiflorus Hack., Monogr. Phan. 6: 338. $1889 . \quad$ Fig. 1d-e Perennial, caespitose, 54-90 cm high. Leaf blades 5-13 cm long, 4-7.5 mm wide, greenish. Inflorescence corymbiform, congeste to subcongeste, with 75-130 racemes; rachis internodes and pedicels flexuous at maturity. Spatheole 12-17(-19) mm long. Peduncle of each raceme 12-18 mm long, slightly longer than the spatheole, at maturity. Rachis internode 2.5-4 mm long. Sessile spikelet: lower glume 3.5-5.5 $\mathrm{mm}$ long, $0.4-0.7 \mathrm{~mm}$ wide between the keels; upper lemma awned, the awn 6.5-12 mm long. Pedicellate spikelet: lower glume 1.5-3 mm long, awned, the awn (1-) 1.5-2.5 mm long.

Material examined: São Pedro do Sul, BR-287 to Santa Maria, 21.XII.2010, H.M. Longhi-Wagner \& C.A.D. Welker 10844, 10845 (ICN); 5.II.2012, C.A.D. Welker 399 (ICN).

Additional material: GOIÁS: Alto Paraíso de Goiás to Teresina de Goiás, 21.VII.1994, S.C. Boechat \& T. Filgueiras 83 (ICN). PARANÁ: Jaguariaíva, Rio das Mortes, 21.I.2001, L. von Linsingen 547 (ICN). Ponta Grossa, 28.I.1946, J.R. Swallen 8299 (PEL).

Schizachyrium lactiflorum occurs in Colombia, Bolivia, Paraguay, Argentina and Brazil (Rosengurtt et al. 1968; Peichoto 2010). In Brazil, it occurs from the States of Goiás to Santa Catarina (Rosengurtt et al. 1968; Peichoto 2010) and in the State of Rio Grande do Sul. We found only one population of this species in the Central region of Rio Grande do Sul (29³9'09.2”S 5409'07.2”W), in humid grassland.

Schizachyrium lactiflorum is morphologically similar to $S$. condensatum (Kunth) Nees due to the shape of the inflorescence. Schizachyrium condensatum differs especially by having the peduncle of each raceme $2.5-5.5 \mathrm{~mm}$ long, much shorter than the respective spatheole, at maturity. Moreover, it presents narrower leaf blades, $2.7-4.5(-5) \mathrm{mm}$ wide, and the lower glume of the pedicellate spikelet with a shorter awn, 0.4-1.1 $\mathrm{mm}$ long. Schizachyrium condensatum occurs from Mexico to Argentina, Uruguay and Brazil (Filgueiras 2003; Peichoto 2010).

\section{Acknowledgments}

The authors thank the curators of the cited herbaria for the loans of specimens. CADW and HMLW thank the Brazilian Research Council (CNPq) for $\mathrm{PhD}$ and research fellowships, respectively. 


\section{References}

Clayton, W.D. \& Renvoize, S.A. 1986. Genera graminum: grasses of the world. Her Majesty's Stationery Office, London. 389p.

Filgueiras, T.S. 2003. Schizachyrium Nees. In: Zuloaga, F.O.; Morrone, O.; Davidse, G.; Filgueiras, T.S.; Peterson, P.M.; Soreng, R.J. \& Judziewicz, E.J. (eds.). Catalogue of New World grasses (Poaceae): III. Subfamilies Panicoideae, Aristidoideae, Arundinoideae and Danthonioideae. Vol. 46. Contributions from the United States National Herbarium. Pp. 560-569.

Peichoto, M.C. 2010. Revisión taxonómica de las especies del género Schizachyrium (Poaceae: Andropogoneae) de Sudamérica. Candollea 65: 301-346.

RBH. 2011. Rede Brasileira de Herbários. Sociedade Botânica do Brasil. Available in <http://www. ufrgs.br/taxonomia/herbarios.asp>. Access on 14 Sep 2011.

Rosengurtt, B.; Arrillaga de Maffei, B.R. \& Izaguirre de Artucio, P. 1968. Especies nuevas y notas taxonómicas de gramíneas en Uruguay y Paraguay. Las especies afines a Schizachyrium condensatum de Uruguay y Paraguay. Boletín Facultad de Agronomía Montevideo 103: 25-41.

Thiers, B. 2011. Index Herbariorum: a global directory of public herbaria and associated staff. New York Botanical Garden's Virtual Herbarium. Available in $<$ http://sweetgum.nybg.org/ih/>. Access on 14 Sep 2011.

Zanin, A. 2010. Schizachyrium Nees. In: Forzza, R.C. et al. (orgs.). Catálogo de plantas e fungos do Brasil. Vol. 2. Instituto de Pesquisas Jardim Botânico do Rio de Janeiro, Rio de Janeiro. P. 1513. 